\title{
Perceived Assessment Instructional Skill Needed by Primary School Teachers for Improving Teaching in Enugu State
}

\author{
Elizabeth N. Ebizie ${ }^{1}$, Obiageli C. Njoku ${ }^{1}$, Charles A. Oraelosi ${ }^{1}$, Juliana N. Ejiofor ${ }^{1}$, \\ Okpala Edith Amaka ${ }^{1} \&$ Mkpoikanke Sunday Otu ${ }^{1}$ \\ ${ }^{1}$ Department of Educational Foundations, University of Nigeria, Nsukka, Nigeria \\ Correspondence: Obiageli C. Njoku, Department of Educational Foundations, University of Nigeria, Nsukka, \\ Nigeria.
}

Received: December 11, 2019

Accepted: April 6, 2020 Online Published: April 20, 2020

doi:10.5539/gjhs.v12n5p72

URL: https://doi.org/10.5539/gjhs.v12n5p72

\begin{abstract}
This study was carried out to investigate the perceived assessment instructional skill needed by primary school teachers for improving teaching in Enugu State, Nigeria. Two research questions and two null hypotheses guided the study. Descriptive survey design was used in the study. The population of the study consisted of 10, 415 public primary school teachers in Enugu State. Sample size of the study was 1,196 teachers, comprising of 579 males and 617 female teachers. Multistage sampling technique was used in the selection of the sample size. Iinstrument used for data collection was 'Perceived Assessment Instructional Skill Needed by Teachers Questionnaire (PAISNTQ). To determine the internal consistency of the instrument, Cronbach Alpha was usedand the result yielded 0.87 . The data collected from questionnaire were analyzed using mean, standard deviation and T-test statistics. The results of the analysis revealed that assessment instructional skills teachers are: assessing the area of pupils' needs through observation; finding out areas of weakness and strength in pupils by asking them questions; assigning homework, quiz and examination to pupils. Also, the results of the analysis revealed that there is no statistically significant difference in the mean rating of male and female teachers on the perceived assessment instructional skill needed by primary school teachers for improved teaching; and that there is no statistically significant difference in the mean rating of teachers in urban and rural public primary schools on the perceived assessment instructional skills needed by primary school teachers for improved teaching. Based on the findings of the study, the researchers recommended, among others, that the assessment instructional skills discussed in this study should be integrated into the teacher education curriculum; and that primary school teachers should be constantly appraised in the area of assessment instructional skills.
\end{abstract}

Keywords: assessment instructional skill, primary school teachers, teaching, Enugu State

\section{Introduction}

Assessment appears to be the hub around all in the teaching and learning process. Hence, teachers' ability, knowledge and other skills may not make teachers worthy except where they are equipped with the skill for assessing the pupils and themselves. Assessment involves the collection and interpretion of data about the knowledge, skills and attitudes of a person or group, in order to facilitate decision-making (Obiweluozo, 2011). It is the procedure of gathering and discussing information from multiple and diverse sources in order to develop a deep understanding of what pupils comprehend and can do with their knowledge as a result of their educational experiences (Lucas, 2014). It is an instrument or scheme of obtaining information from tests or other sources about the achievement or abilities of individual learners and the competence of the teacher. Assessment is very important to instructional practices because it influences decisions about grades, position, advancement, instructional needs, curriculum and teachers' effectiveness (Daniel, 2008). There is observational evidence that primary school teachers need to develop their skills in both self-assessment and assessment of the pupils. Assessment instructional skills are frequently used by teachers to evaluate pupil's achievement.Assessment instructional skill helps the teacher to know pupil's ability. A further aspect of assessment to be discussed in this connection is that it can help teachers to assess the kind of home conditions of some pupils and attitude of others to their work. However,Knight (2011), points out that assessment provides 'feed out' in the form of a warrant to achievement or competence (such as a degree certificate) and in cognizance of information that can be used as performance indicators in appraising the work of teachers, college, national systems of education, among others. However, assessment instructional 
skills could be employed to identify what pupils need to do in order to improve their work (Lejk \& Willy, 2009). In respect of the above definitions it involves using carefully designed tasks to try and identify barriers to teaching, helps teacher to identify those pupils who are honest with their work and hard-working. In other words, assessment does not neccesarily mean testing, even though tests and examination are ways of assessing. Assessment instructional skills planned, ideally prepared task by teachers given to pupils to ascertain their performance in the classroom (Knight, 2011).

From the classroom perspectives, assessment instructional skill is an on-going process of gathering evidence by the teachers to determine the mastery or rather attainment of stated objectives in terms of what each pupil can do and demonstrate at the three domains of behavioural objectives so as to inform teaching and support learning of the intended outcome. Uju and Adaka (2010) concurred that assessment instructional skill enhances the provisions of optimum conditions for learning and hence maximizes pupils' achievement. When instruction occurs, it gives pupils the opportunity to learn what the intended learning is and assessment enables pupils to demonstrate their learning of what has been taught.

There are research evidences that assessment instructional skill is an ongoing process which involves the totality of the view that the teacher does to determine the amount of learning that has taken place in the pupils. Assessment is a key component of learning because it encourages pupils to learn. When pupils are able to see how they are doing in a class, it motivates them. It has been noted, according to Gronlund (2011) that assessment can facilitate pupils' learning directly or indirectly. Since objective assessment cannot take place without use of valid instruments, the relevance of assessment skills for effective instruction cannot therefore be overstressed. According to Abonyi (2010) stated that assessment instructional skills for the primary school teachers includes clarifying of instructional objectives, pre-assessment of pupils' needs, monitoring of pupils progress and diagnosing and remedying pupils difficulties as well as appraisal of pupils outcomes.In order to improve learning, pupils need to receive appropriate and determine whether or not they understand what they are learning.In so doing, teachers focused on feedback early and often; they also need to learn how to assess their own competence. Assessment instructional skill is regarded as part of the professional practice of teachers (Uju \& Adaka, 2010). Assessment instructional skills guide teachers to plan appropriate teaching; learning strategies, including identifying pupils who are falling behind in their class or who need additional support, and enable pupils to make reasonable progress in their studies.

As Santrock (2013) rightfully noted, assessment provides a teacher with the valuable information for providing optimal learning experiences for every child. Today's primary school teachers should be conversant with not only the basic content, but also skills that will enable them to face a world that is continually changing.Further more, they must be able to think critically, to analyze, and to make inferences and the content that is being assessed. There has been a lot of emphasis on effective assessment instructional skill. Primary school teachers should be actively involved in decision making about the purpose of assessment instructional skills. Successful assessment strategies allow the primary school teachers to fairly and accurately evaluate the real learning of all the pupils in the classroom.

Assessment provides primary school teacher opportunity to discover where a pupil's true interests, talents, values and abilities lies. Research evidences indicate that assessment instructional skill is a key component of learning because it helps the primary school teacher to assess himself and evaluate the pupil to know or to determine whether or not they understanding what he taught them. Assessment also help motivate the teacher to put more effort to carry out the responsibility of presenting the learning contents to the pupils in the classroom, just as assessment helps pupils to know their ability, assessment also helps teacher to know their competence (Hilgerson \& Karin, 2013). It implies that assessment instructional skill will help the teacher to create goals and understand one's personality. It is also necessary to appreciate the fact that assessment is conducted when instruction is in progress (formative) to monitor pupils progress during the course of instruction (Abonyi, 2010).Therefore, assessment in the context of this study, is the procedure of documenting, usually in measurable terms, the knowledge, skills, attitudes and beliefs of both the primary school teachers and the pupils with the aim to improving teaching and learning processes in the classroom or a plan, a device the teacher utilizes to monitor pupils progress in the course of instruction. This could be in written form or oral communication.

In the recent times,there has been remarkable decline in therate of performance of students in schools. The public opinion about the abysmal standard of achievement of students graduating from schools in Nigeria in the recent time has reached an alarming climax.As a result of low academic competence of the Nigeria graduates unemployment is on the increase because they are being rejected in the labor market. Onah (2012) and Emaikwu (2012) opined that the decline in standard of achievement by students at all levels of education has been strongly 
reported and affirmed by various stakeholders in Nigeria.

This decline in the standard of achievement at post primary level is unquestionably caused by the pedagogical approaches adopted by teachers in schools which customarily results in poor learning. Reports showed that in Nigeria learning and understanding of school subjects have been frustrated by the inept methods of instructional delivery which manifests itself in the low achievement and retention level in students' outcome in examinations (Etukudo, 2006). Nevertheless, people have been talking about the inadequacies with the method of assessment in schools, such as continuous assessment practice, emphasis on cumulative test scores, ill-preparedness on the part of the teachers who implement the policy, are nothing to write home about. The teacher-made tests, which form the bases of the present assessment practice in schools, make it difficult in the maintenance ofacceptable standardsin educational system. Further more, unacceptable standardization and inaccurate interpretation of test results are some of the evaluation problems, which pose great threat to the teachers in schools. Most of schools still dwell in the past as regards the way the students are being assessed which revolves around preparing them for examinations. As result of this trend, every student strives for high marks with out having indepth knowledge of what is learnt and its application in real life suitation; because of an over emphasis on paper-and-pencil assessments. Very slight attention is given to the "higher mental task thinking and applications". This brings to the fall in the ability to put into practice the acquired knowledge in real-world; to analyze the information; to synthesize new information based on what was learnt; and to evaluate the outcome of knowledge applied. Summarily, in Nigeria, assessment is carried out after teaching has been completed (Emaikwu, 2014).

Apart from assessment skills, another factor that could determine instructional effectiveness of teachers is gender. Researchers have focused considerable attention on the relationship between gender and effective teaching. For instance, experts like Ayodeji (2009) and Keller (2011) have noted that gender and location could mar teaching. Nwafor (2013) defined gender as the act of being male or female, man or woman. It represents the differences in both sex, either male or female, boy or girl, man or woman. Gender is the condition of being masculine or feminine through one's behaviour (Sinclair, 2013). This means that there are behaviours meant for males and there are the ones meant for females. Obasi (2009) perceived gender as many social and cultural constructed characteristics, qualities, behaviour and roles which different societies ascribe to male and female. In this present study, gender is the manifestation of assessment instructional skills by male and female teachers for improving teaching. Previous research by Onyeke (2013) suggested that male teachers and female teachers are likely to differ in their kind of instructional skills. Hornby (2011) opined that female teachers are more likely to discriminate than the male teachers in teaching in the classroom (Nwafor, 2013). Jacklin and Lacey (2007) concurred that male teachers exhibit good organizational and grouping strategies than their female counterparts. It is based on this background that the present study seeks to determine the gender differences on assessment instructional skills of teachers.

Apart from gender, school location could be another determinant of assessment instructional skills of teachers. It has been noted by Aluko (2014) and Anagbogu (2012) that quality instructional outcome is more prevalent in the cities than in the rural locations. Aluko asserts that teachers in urban locations enjoy enough facilities that enable them to give quality instructional outcomes than those in rural areas. School location refers to the place where a school is sited. It is called the geographical location of the school (Jones, 2009). Some primary schools in Enugu State are located in urban areas while some are located in the rural areas. Urban areas here mean township or metropolitan parts of Enugu State. Rural areas mean local areas or undeveloped parts of Enugu State. There is speculation that teachers with better assessment instructional skills are posted to urban areas, while those who teach in rural areas possess poor assessment instructional skills. The outcome of the present study will reveal whether location determines the assessment instructional skills of teachers in Enugu State

In Enugu State, various recent researches have focused on how to improve the quality of primary education. For instance, Nwanna (2012), Onah (2014) and Onyia (2016) had all focused their studies on ways of improving primary school education in Enugu State. The reason for this research is not far-fatched, reason is that the clearly observed evidence that the quality of primary education in Enugu State is degrading rapidly. In addition, Omeke (2014) in his study lamented that primary school pupil's performance and intellectual growth fall below the expected standards in Enugu State.

Generally speaking, there is much decline in the standard of education in Nigeria but this does not substitute the fact that Enugu State is one of the states that seem to be more affected, especially when assessed from the angle of intellectual competence of First School Leaving Certificate (FSLC) holders of 1960s and those who hold FSLC especially in public schools today. No doubt, from such assessment, one would quickly agree that the intellectual performance of pupils passing out of schools has continued to decline. A study conducted by Ezema (2014) to compare the intellectual performance of First School Leaving Certificate holders of 1960s and twenty first century 
in Enugu State revealed that there is a wide gap between these same certificate holders. To backup the findings of Ezema, it is presumed by some people in Enugu State that the First School Leaving Certificate holders of 1960s and 70s are equivalent to First Degree holders of today. For instance, Obilor (2015) argues that by the time some pupils obtained FSLC in the 1960s and 70s, they had become academically sound to be employed as teachers and office clerks which are rarely possible in Enugu State in this century.

In addition, the internal and external examinations of primary school pupils in Enugu indicate that there is poor academic achievement among primary school pupils (Onyeke, 2016). The progressive reports of primary school pupils which the researchers were able to assess prior to this research also revealed that there is poor academic achievement among the pupils in public primary schools. This observation and other empirical evidence point to the fact that something could be wrong with either the assessment instructional skills of the teachers or the understanding of pupils on what they are being taught. However, the researchers dwells on the earlier findings of Ezema (2014) which revealed that there are poor instructional skills of primary school teachers in Enugu State to carry out the present study. Against this background, the interest of this study is to find out the assessment instructional skill needs of public primary school teachers in Enugu State.

Ngugi (2010) carried out a study to investigate the degree assessment skills of teachers influence students' academic performance in English Language in public post primary schools in Naivasha District. The purpose of the study was to determine the extent teachers pedagogic skill influence students' academic achievement in English Language in public secondary schools. The study was guided by three research questions and one null hypothesis. The design adopted was descriptive survey. A twenty-item questionnaire was structured to gather relevant data for the study. The sample size consists of one hundred and twenty teachers. Questionnaire was the instrument for data collection. Purposive sampling technique was adopted for the study. Mean scores were used to answer the three research questions while t-test statistics was used to test the null hypothesis. The findings of the study revealed that teachers' instructional skills influence students' academic performance in English Language but that majority of the teachers lack such skills for teaching the subject. The study is related to the present study because both have instructional skill teachers as variables of interest. However, the study is different from the present study in scope and respondents used. While the purpose of the study was on the extent teachers' pedagogic skills influence students' academic achievement in English Language in public secondary schools in Naivasha District, the present study has its interest on instructional skill needs of the primary school teachers for improving teaching and learning in Enugu State. In addition, the study was carried out in foreign country, and not here in Nigeria.

Amechi (2017) assessed the pedagogical skills of teachers in teaching tertiary institution students. The purpose of the study was quality assurance of English Language teacher education in tertiary institutions in Enugu State. Five research questions were posed and answered by this study. Two hypotheses were formulated and tested at 0.05 level of significance. The study adopted mixed descriptive design involving quantitative (survey) and qualitative methods (observation) to collect primary data. The population of the study is 1290 respondents comprising 93 lecturers and 1197 students of the Department of English Language in four tertiary institutions in Enugu State. There was no sampling because of the small size of the population. Instrument for data collection was researchers' developed questionnaire titled Quality Assurance Questionnaire (QAQ) and Observation Schedule. The instruments were given to three experts for validation. The data collected were analyzed using frequency, percentage for section A and mean and standard deviation for section B. Independent Sample t-test was used to test the hypotheses at 0.5 level of significance. The findings of the study revealed that the lecturers have high level knowledge of the content of English Language and have the pedagogical skills for teaching the subject. This study is related to the present study because one of its variables is on pedagogical skills which are similar to assessment in instructional skills raised in the present study. In contrast, the purpose of this study is quality assurance of English Language teacher education in tertiary institutions and not instructional skill needs of primary school teachers for improving teaching and learning in Enugu State.

A study concerning assessing the sustainability and teachers performance for information communication technology (ies) in enhancing the quality of teaching English language in Ogun State was conducted by Adekola (2009). The study adopted an ex-post facto design. Four research questions guided the study. The target population for the study comprised all secondary school English teachers in Ogun State. The sample was 400 teachers drawn from the four zones in Ogun State (Ijebu, Egba, Remo and Yewa) using simple random sampling technique. The data analysis was done using frequency and percentage. The result indicates that ICT and other multimedia tools are very suitable for teaching and learning of the subject. It also revealed that majority of the teachers show high preferences for video as a multimedia tool. Relating the study to the present study at hand, the researchers will know the teacher preferred teaching strategy for effective teaching and learning which the main objective of this 
study is. The study has relationship with the present study because both of them are geared towards improve teaching and learning. However, the researchers used ex-post facto design that had few respondents. This is one of the areas the present study has narrowed.

Madu and lyiola (2013) studied on needs assessment of Nigerian post primary school science teachers for improvement of science instruction in Taraba State in Nigeria. Study conducted was to examine the capacity needs of post primary schools science teachers for acquisition of competencies for science instruction in Taraba State, Nigeria. Two research questions and two hypotheses were formulated for the study.Study made use of survey research design with a total sample of 360 post primary school science teachers that was selected through proportionate stratified random sampling technique. A ten item multiple choice test structured questionnaire were developed for obtaining data on capacity building needs for planning of science instruction.Instrument face validated by 3 experts and the reliability coefficient of 0.90 was obtained using Cronbach alpha method. Data collected were analyzed using mean and improvement needed index (INI). Study found out that capacity building is highly needed by the science teachers for planning of science instruction. The results further showed that science teachers need programme for a periodic retraining in form of in-service programmes to improve their instructional skills. The study is related to the current study because teachers need acquisition of competencies to improve their assessment instructional skills. However, the study did not use other teachers than science teachers. Hence, the gap the current study sought to fill.

Descriptive survey design was adopted for the study to investigate the perceived assessment instructional skill needed by primary school teachers for improving teaching in Enugu State. According to Ali (2006) descriptive survey design as we know is concerned with describing events as they are, without any manipulation of what caused the event or what is being observed. In descriptive surveys, views, facts, among others are collected, analysed and used for answering research questions. The descriptive survey design was considered most appropriate for the study because it permits the collection of original data from the respondents themselves, describes the present conditions as they are in their natural school settings, and allows only a representative of the population to be sampled.

\subsection{Research Questions}

1. What are the mean responses of male and female teachers on the assessment instructional skills needed for improving teaching?

2. What are the mean responses of urban and rural teachers on the assessment instructional skills needed for improving teaching?

\subsection{Hypothesis}

Ho1 There is no significant difference in the mean rating of male and female teachers on the assessment instructional skills needed for improving teaching.

H02:There is no significant difference in the mean rating of urban and rural teachers on the assessment instructional skills needed for improving teaching.

\section{Materials and Method}

This study was carried out in Enugu State. Enugu State is one of the states in South East Nigeria. The population of this study was 10,415 public primary school teachers in Enugu State. Statistics available show that there are 1,220 public primary schools in Enugu State while there are 10,415 teachers who are teaching in the State public primary schools. The sample for the study was 1196 which consists of 579 male and 617 female primary school teachers drawn through multistage sampling technique.In the selection of the teachers, $30 \%$ of them was selected through Proportionate Sampling Technique, hence, the following sample size: 184, 256, 192, 196, 198 and 170. These gave a total number of 1,196 primary school teachers.

Instrument for data collection was a questionnaire titled Perceived AssessmentInstructional Skill Needed by Primary school Teachers Questionnaire (PAISNPTQ). The questionnaire consists of two sections. Section A and Section B. Section A comprised information regarding the personal data of primary school teachers such as gender, location and education zone. Section B contained items built in one cluster, A. A four-point rating scale was provided for the respondents to indicate the strength of their opinion as follows: Strongly Agree (SA) $=4$, Agree $(\mathrm{A})=3$, Disagree $(\mathrm{D})=2$ Strongly Disagree $(\mathrm{SD})=1$ for the clusters. Cluster A addressed assessment (instructional) skill needed by primary school teachers for improved teaching,

Instrument was subjected to face validation by three experts in the University of Nigeria, Nsukka. To determine the internal consistency of the instrument, trial testing of the instrument was carried out in Awka Education Authority 
of Anambra State using 30 respondents (teachers) in public primary schools. The choice was because they share the same type of environment with Enugu State. This trial testing was to enable the researchers to determine the internal consistency reliability estimate of the instrument using Cronbach Alpha Statistic. The analysis of data yielded Alpha co-efficient estimate values of 0.94 . This high co-efficient estimate value reveals that the instrument is reliable to be used for the study.

The researchers analyzed the data collected using mean and standard deviation in order to determine the degree to which each questionnaire items was agreed to. In taking a decision in each of the research questions, mean scores of 2.50 and above on the four-point rating scale was considered acceptance, while those below 2.50 was regarded as rejection. The t-test statistics was employed to test the null hypotheses at 0.05 level of significance

\section{Results}

Table 1. Mean responses of male and female teachers on the assessment instructional skills needed for improving teaching (N-1196)

\begin{tabular}{|c|c|c|c|c|c|c|c|}
\hline \multirow{2}{*}{$\mathbf{S} / \mathbf{N}$} & \multirow{2}{*}{ ITEMS } & \multicolumn{2}{|c|}{ MALES } & \multicolumn{4}{|c|}{ FEMALES } \\
\hline & & $\overline{\bar{x}}$ & SD & RMK & $\overline{\mathrm{X}}$ & SD & RMK \\
\hline & Teachers need to: & & & & & & \\
\hline 1. & Assess the area of pupil's need through observation & 3.75 & .60 & Agree & 3.65 & 0.70 & Agree \\
\hline 2. & $\begin{array}{l}\text { Find out areas of weakness and strength in pupils by asking them } \\
\text { questions }\end{array}$ & 3.67 & .67 & Agree & 3.56 & 0.73 & Agree \\
\hline 3. & Assign home work to pupils. & 3.52 & .79 & Agree & 3.50 & 0.77 & Agree \\
\hline 4. & Ask pupils to read after them. & 3.47 & .76 & Agree & 3.40 & 0.77 & Agree \\
\hline 5. & Give quiz in the classroom. & 3.33 & .84 & Agree & 3.27 & 0.84 & Agree \\
\hline 6. & Give examination to test the pupils. & 3.34 & .82 & Agree & 3.44 & 0.76 & Agree \\
\hline 7. & Ask pupils to write after them. & 3.29 & .87 & Agree & 3.33 & 0.83 & Agree \\
\hline 8. & Ask pupils to draw after them. & 3.38 & .79 & Agree & 3.23 & 0.94 & Agree \\
\hline 9. & Always make use of computers in assessing the pupils & 1.31 & .87 & Disagree & 1.19 & 1.00 & Disagree \\
\hline 10. & Re-evaluate from time to time the pupils' needs. & 3.29 & .88 & Agree & 3.29 & 0.91 & Agree \\
\hline 11. & Ask questions to pupils in class & 3.38 & .84 & Agree & 3.22 & 1.02 & Agree \\
\hline
\end{tabular}

From Table 1 above, the male teachers and female teachers in Enugu State both agreed on the same items on assessment instructional skills needed by teachers for improving teaching. They also disagreed on the same items on assessment instructional skills needed by teachers for improving teaching.

Table 2. Independent t-test Analysis of male and female teachers on the assessment instructional skill needs of teachers for improved teaching $(\mathrm{N}=1196)$

\begin{tabular}{llllllll}
\hline Gender & $\mathbf{N}$ & $\mathbf{X}$ & SD & Df & t-cal & Sig-t & Remark \\
\hline Male & 579 & 3.39 & 0.45 & 1194 & -1.09 & 0.27 & Not significant \\
Female & 617 & 3.42 & 0.40 & & & & \\
\hline
\end{tabular}

From Table 2, the calculated t- value (-1.09) had degree of freedom 1194 and is significant at 0.27 level off significance; the value is higher than the chosen $0.05 \mathrm{p}$-value. Therefore, the null hypothesis of no significant difference in the mean ratings of male and female teachers on the assessment instructional skill needs was accepted; hence, there is no significant difference in the mean ratings of male and female teachers on their assessment instructional skill needs for improved teaching.

\section{Discussion}

The results showed that the teachers agreed on the assessment instructional skill needs identified by the researchers 
for improved teaching in Enugu State. Therefore, there is need for teachers to assess the area of pupils' need through observation; find out areas of weakness and strength in pupils by asking them questions; assign homework, quiz and examinations to the pupils, re-evaluate from time to time the pupils' needs and ask questions to pupils in class.

This finding substantiated the earlier study of Obiweluozo (2011) who reported that pre-primary school children need to be assessed from time to time to improve their learning outcome. The findings of the study is also in line with the study conducted by Afemikhe and Omo-Egbekuse(2012) which revealed that school-based assessments within school setting are composed of the following: continuous assessment, end-of term and end-of-year examinations. Continuous assessment as mentioned by Afemikhe and Omo-Egbekuse' study is similar to assigning home works and quiz to the pupils. The findings of the study also corroborates the earlier findings of Awapila (2008) which assessed the instructional skills of teachers in post primary schools in Markurdi, Benue State, and revealed that teachers need assessment instructional skills to improve the academic performances of the pupils.

\section{Conclusion}

The authors of this study concluded that the assessment instructional skills needs include assessing the area of pupils' needs through observation, finding out areas of weakness and strength in pupils by asking them questions; assigning homework, quiz and examination to pupils. These needs are not different significantly among male and female teachers.

\section{Competing Interests Statement}

The authors declare that there are no competing or potential conflicts of interest.

\section{References}

Abonyi, O. S. (2010). Assessment tools. Journals of Education, 1, 82-93.

Adekola, A. (2009). Assessing the sustainability and teachers performance for information communication technology in enhancing the quality of teaching english language. Journal of Curriculum Studies, 16(4) 75-83.

Afangideh, M. E. (2009). Towards effective teaching and learning of poetry in the secondary school in Essieu. Journal of Curriculum Studies, 16(4), 117-124.

Afemikhe, O. A., \& Omo-Egbekuse. (2012). Implementation of continuous assessment in Nigeria primary schools: Observations of the Binin State case. Benin Journal of Educational Studies, 8(1\&2), 205-211.

Ali, A. (2009). Conducting research in education and the social sciences. Enugu: Tashiwa Networks.

Aluko, U. (2014). Quality instructional outcomes: Teachers' guide. Enugu. Han's publishing.

Amechi, A. C. (2017). Assessment of quality assurance of English Language teacher education in tertiary institutions in Enugu State (Master's thesis). University of Nigeria, Nsukka.

Anagbogu, M. A. (2012). Teachers' instruction in the classroom. Journal of Education, 2(1), 91-101.

Ayodeji, A. O. (2009). Gender difference on locally standardized anxiety rating scale in English Language for Nigeria secondary schools. Journal ofCounselling Applied. Psycho, 1(2), 30-41.

Ayodeji, I. (2009). Gender and middle basic education social studies curriculum: a conceptual overview. Journal of Curriculum Studies, 16(4), 189-199.

Daniels, H. (2008). Literature circles: Voice and choice in book clubs and reading groups. Portland, ME: Sten house.

Emaikwu, S. O. (2014). Issues in the assessment of effective classroom learning in Nigeria. Journal of humanities and Social science (JHSS), 19(10), 1-8. https://doi.org/10.9790/0837-191020108

Emaikwu, S. O. (2012). Assessment of the impact of students' mode of admission into university and academic achievement in Nigeria. International Journal of Academic Research in progressive Education and Development, (3), 23-30.

Etudor-Eyo, E., Akpan, C. C., Akuegwu, B. A., \& Bisonog, C. K. (2011). School physical environment and teachers' instructional effectiveness. Journal of OMEP, $7 \& 8(1), 117-125$.

Etukudo, U. E. (2006). The effect of computer assisted instruction on gender and performance of junior secondary school in mathematics. ABACUS Journal of Mathematics Association of Nigeria, 27(1),1-8. 
Ezema, P. (2014). Assessment of primary school teachers instructional competence in Enugu State (Master's thesis). Enugu State University of Science and Technology, Enugu.

Hilgerson, \& Karin, M. (2013). Achieving equity and excellence through improved assessment. Oregon School Study Council.

Hornby, A. S. (2011). Oxford advanced learner's dictionary of current English (6th ed.). Oxford university press.

Jacklin, S., \& Lacey, A. (2007). Counselling as instruction for exceptional youths in the universities.Journal of Psychologists, 6(4), 403-409.

Knight, R. (2011). Educational planning and assessment. Enugu: Computer Edge publishers.

Lejk, S., \& Willy, N. (2009). Diagnostic assessment: A handbook. New York: Beanfort.

Madu, B.C., \& lyiola, F. B. (2013). Needs assessment of Nigerian senior secondary school science teachers for improvement of science instruction in Taraba State in Nigeria. Developing Country Studies 3(9), www.iiste.org

Ngugi, N. (2010). Influence of teachers' pedagogic skill on students academic achievement in English Language in public secondary schools in Naivasha District (Master's thesis, University of Kenya).

Nwafor, R. (2008). The relationship between gender and location and inclusive classroom. Journal of the National Council for Exceptional Children, 2(1), 107-115.

Nwanna, J. (2012). Effective strategies for improving primary school pupils' teaching and learning in Enugu State (Master's thesis). University of Nigeria, Nsukka.

Obasi, E. O. (2009). Encouraging gender equality secondary education.Journal of Curriculum Studies, 16(4) 61-74.

Obilor, C. (2015). Factors affecting achievement in primary education in Enugu State (Master's thesis). University of Ilorin.

Obiweluozo, E. P. (2011). Assessment needs of pre-primary school children for effective teaching and learning. Journal of OMEP, $7 \& 8(1), 1$.

Omeke, I. (2014). Assessment of primary school pupils' academic performances in Enugu State (Master's thesis).Kogi State University, Anyimg

Onah, A. E. (2012). Effect of motivation on students' performace in mathematics. An undergraduate project submitted at the federal university of Agriculture, Makurdi.

Onah, K. (2014). Instructional strategies for improving primary school pupils' academic performance in Enugu State (Master's thesis,Ebonyi State University).

Onyia, M. (2016). Assessment of instructional designs for improving pupils' academic achievement in Enugu State (Master's thesis, NnamdiAzikiwe University, Awka).

Onyeke, L. (2016). Assessment of primary school pupils' academic achievement in Enugu State (Master's thesis, NnamdiAzikiwe University, Awka, Anambra State).

Santrock, A. (2013). Students' learning techniques. http://www.stu/lear/santrock.htm. Retrieved on 5/3/2014.

Sinclair, J. (2013). B.B.C. English dictionary. Lagos: Africana Fep publishers.

Uduak, G. M. (2009). Encouraging gender equality in secondary education: implications of teaching strategies and students' gender on academic performance in introductory technology. Journal of Curriculum Studies, 16(4) 61-74.

Uju, N., \& Adaka, T. A. (2010). Guidelines for assessing students' achievement. Journal of Education, 1(3), 124-134.

\section{Copyrights}

Copyright for this article is retained by the author(s), with first publication rights granted to the journal.

This is an open-access article distributed under the terms and conditions of the Creative Commons Attribution license (http://creativecommons.org/licenses/by/4.0/). 